(c) American Dairy Science Association, 2005.

\title{
Effects of Feeding Propionate and Calcium Salts of Long-Chain Fatty Acids on Transition Dairy Cow Performance*
}

\author{
J. M. DeFrain, ${ }^{1}$ A. R. Hippen, ${ }^{1}$ K. F. Kalscheur, ${ }^{1}$ and R. S. Patton ${ }^{2}$ \\ ${ }^{1}$ Dairy Science Department, South Dakota State University, Brookings 57007 \\ ${ }^{2}$ Galisteo, NM 87540
}

\begin{abstract}
Multiparous Holstein cows $(\mathrm{n}=40)$ were used in a randomized complete block design to determine the effects of feeding $\mathrm{Ca}$ and $\mathrm{Na}$ salts (1:1, wt/wt) of propionate and Ca salts of long-chain fatty acids (LCFA) on transition cow performance. All cows were fed the same basal diet once daily for ad libitum intake. Treatments (g/d) were 320 cornstarch (CS) as a control, 120 propionate (PRO), 120 propionate and 93 LCFA (PF1), and 178 propionate and 154 LCFA (PF2). Treatments were hand-mixed into the upper one-third of the TMR from 2 wk pre- through 3 wk postpartum. Intakes were recorded from $21 \mathrm{~d}$ pre- through $21 \mathrm{~d}$ postpartum. Energy density and crude protein were 1.54 and $1.65 \mathrm{Mcal} /$ $\mathrm{kg}$ and 14.4 and $18.8 \%$ for pre- and postpartum diets, respectively. All cows received a common diet from 22 to 70 days in milk (DIM). Milk composition was analyzed on d 7, 14, and 21. Blood was sampled at 14, 7, and $2 \mathrm{~d}$ prepartum and 2, 7, 14, and 21 DIM. Pre- and postpartal dry matter intake (DMI) averaged 11.9 and $16.4 \mathrm{~kg} / \mathrm{d}$, respectively, and did not differ among treatments. A diet $\times$ week interaction for postpartal DMI was observed as cows fed PF2 consumed $2 \mathrm{~kg} / \mathrm{d}$ less DM during wk 2 relative to other treatments. Milk yields from 22 to 70 DIM were 48.8, 48.5, 47.8, and 51.3 $\mathrm{kg} / \mathrm{d}$ for CS, PRO, PF1, and PF2, respectively, and were not significantly affected by treatments. Milk true protein (3.32 vs. 3.16\%) was increased and MUN (12.5 vs. $14.4 \mathrm{mg} / \mathrm{dL}$ ) was decreased for CS relative to other treatments. Milk fat yield from cows fed PRO tended to be greater than those fed PF1 (1.58 vs. $1.29 \mathrm{~kg} / \mathrm{d}$ ). Plasma glucose, insulin, and $\beta$-hydroxybutyrate were not affected by treatments. The PF2 treatment tended to decrease NEFA in plasma relative to PF1 over all times measured (492 and $670 \mu \mathrm{Eq} / \mathrm{L}$ ) and significantly
\end{abstract}

Received June 18, 2004.

Accepted September 30, 2004.

Corresponding author: Arnold R. Hippen; e-mail: arnold_ hippen@sdstate.edu.

*Published with the approval of the director of the South Dakota Agricultural Experiment Station as publication no. 3421 of the journal series. decreased plasma NEFA relative to those fed PF1 postpartum (623 and $875 \mu \mathrm{Eq} / \mathrm{L}$ ). Relative to PF1, feeding propionate and LCFA at the higher level in this experiment improved energy balance postpartum as evidenced by decreased concentrations of plasma NEFA. (Key words: propionate, fat, transition dairy cow)

Abbreviation key: $\mathbf{C S}=$ corn starch (control), ECM = energy-corrected milk, LCFA = long-chain fatty acid, PRO = propionate, $\mathbf{P F 1}=$ propionate + fat level 1 , PF2 = propionate + fat level 2.

\section{INTRODUCTION}

The transition from late gestation to early lactation is regarded as one of the most challenging elements of the production cycle. This transition imposes profound physiologic and metabolic changes. These changes often disrupt the homeostatic mechanisms of the cow because they occur in a matter of days, and sometimes hours, as the liver adapts from a minimal glucose demand to an overwhelming demand for glucose. The 3 wk before and after calving is the most important $6 \mathrm{wk}$ of the production cycle as it imparts the level of success realized during the subsequent lactation.

Ruminal propionate is the single most important substrate for gluconeogenesis (Drackley et al., 2001); however, depressed feed intake at parturition is likely limiting ruminal propionate supply to the liver. Estimates by Seal and Reynolds (1993) indicate that propionate supplies 32 to $73 \%$ of glucose demands. Feeding propionate has increased blood glucose (Schmidt and Schultz, 1958; Schultz, 1958) and decreased blood BHBA (Schmidt and Schultz, 1958; Schultz, 1958; Goff et al., 1996). Both drenching (Grummer et al., 1994) and feeding propylene glycol (Christensen et al., 1997) have decreased NEFA and increased insulin in plasma and increased ruminal propionate concentrations, all of which are beneficial to combating the extent and duration of ketosis and fatty liver. Effects of propylene glycol are partially mediated through the observed increases in ruminal propionate (Grummer et al., 1994; Christensen et al., 1997), providing reasons to feed propionate during the transition period. 
Reasons for feeding fat during the transition period are several. Kronfeld (1982) introduced the concept of the glucogenic to lipogenic ratio, suggesting that the mammary gland may be deficient in precursors for triglyceride synthesis, particularly at a time when milk fat content is the greatest. In a review of lipid-related metabolic disorders in peripartum dairy cows, Grummer (1993) hypothesized dietary fat could decrease fatty acid mobilization, sparing mammary glucose oxidation by decreasing amounts of NADPH necessary for mammary fatty acid synthesis. Reported effects of feeding fat, either tallow (Skaar et al., 1989; $960 \mathrm{~g} / \mathrm{d}$ ) or prilled fat (Selfer et al., 1995; $350 \mathrm{~g} / \mathrm{d}$ ) during the transition period have been few. Fat escaping rumen fermentation leaves the small intestine as chylomicrons to be absorbed by extrahepatic tissues and does not contribute to hepatic lipidosis because of the absence of lipoprotein lipase in liver (Emery et al., 1992).

Of particular interest in our experiment was the role of fatty acids on the carbohydrate status of peripartum dairy cows. Previous in vitro and in vivo work demonstrated the synergism of fatty acids and propionate metabolism during gluconeogenesis. Ferre et al. (1978) speculated the hepatic oxidation of fatty acids could provide the ATP, acetyl CoA, and NADH cofactors necessary for maximal gluconeogenic capacity. Following a 16-h fast, they found circulating glucose concentrations of neonatal rats injected with glucogenic substrates to increase 2-fold (from 1.1 to $2.6 \mathrm{mM}$ ), whereas a similar injection into rats previously fed triglycerides increased blood glucose 4-fold (from 1.1 to $4.7 \mathrm{mM}$; Ferre et al., 1978). Based on in vitro work with sheep hepatocytes, Lomax et al. (1986) proposed that reducing equivalents from fatty acid metabolism affect the transport of carbon atoms across the mitochondrial membrane. This is of particular importance when shuttling malate carbon during gluconeogenesis in the transition dairy cow. Most recently, blood glucose and insulin increased and NEFA decreased in cows fed glucose precursors in combination with $\mathrm{Ca}$ salts of fatty acids relative to cows fed the same amount and type of lipids in combination with barley during the transition period (Patton et al., 2004). What is unclear from Patton et al. (2004) is the impact of feeding glucose precursors alone compared with glucose precursors plus fat and whether dosage of lipids and glucose precursors could elicit a greater response. Therefore, our objectives were to use blood metabolites and lactation performance data to determine 1) the effect of feeding propionate with and without Ca salts of fatty acids and 2) whether the synergistic effects of propionate and Ca salts of fatty acids were dose dependent. Our hypothesis was that feeding propionate in combination with fatty acids would increase blood glucose, decrease blood NEFA, and improve lacta- tion performance greater than feeding propionate alone.

\section{MATERIALS AND METHODS}

\section{Cows and Sampling}

The experiment was conducted from January through October of 2003 at the South Dakota State University Dairy Teaching and Research Facility (Brookings, SD). Animal care and use was according to a protocol approved by the South Dakota State University Institutional Animal Care and Use Committee. Forty multiparous Holstein cows were blocked by parity and expected calving date and arranged into a randomized block design $28 \mathrm{~d}$ before expected calving until 70 DIM. The treatment groups consisted of 4 topdresses which were hand-mixed into the upper one-third of the prefresh (starting $14 \mathrm{~d}$ before expected calving) and postfresh (calving through 21 DIM) TMR. The topdresses were (kg/d, DM basis): 0.32 cornstarch $(\mathbf{C S})$ as a control, 0.73 soyhull-propionate pellet +0.21 cornstarch (PRO), 0.73 soyhull-propionate pellet $+0.13 \mathrm{Ca}$ soaps of long-chain fatty acids (LCFA, Megalac, Church and Dwight Co., Princeton, NJ; PF1), and 1.08 soyhull-propionate pellet + 0.19 LCFA (PF2). The cornstarch (Cargill, Inc., Minneapolis, MN) was considered a traditional glucogenic agent as it is primarily fermented to propionate in the rumen. The amounts of propionate fed were determined from the earlier work of Schultz (1958) and Schmidt and Schultz (1958) who fed 114 and $228 \mathrm{~g} / \mathrm{d}$ of $\mathrm{Na}$ propionate, respectively, whereas amounts of LCFA fed were based upon the recent work of Patton et al. (2004). The PF2 treatment was formulated to contain approximately 50\% more propionate and LCFA relative to $\mathrm{PF} 1$. Therefore, treatments were formulated to provide $120 \mathrm{~g} / \mathrm{d}$ of propionic acid for PRO and PF1 and $178 \mathrm{~g} / \mathrm{d}$ for PF2, and LCFA at $93 \mathrm{~g} / \mathrm{d}$ for PF1 and $154 \mathrm{~g} / \mathrm{d}$ for PF2. A treatment of fat alone was not included in our experimental design because effects of feeding fat alone during the transition period have been few (Skaar et al., 1989; Salfer et al., 1995; Patton et al., 2004). All cows received a common diet from 22 to 70 DIM. The ingredient and nutrient composition of diets are shown in Tables 1, 2, and 3.

The soyhull-propionate pellet fed to cows receiving PRO, PF1, and PF2 was manufactured at the South Dakota State University feed mill using a 4.76- $\times 31.75$ $\mathrm{mm}$ (hole diameter $\times$ effective diet thickness) die. The propionate used was a 1:1 (wt/wt) mixture of $\mathrm{Na}$ (Calprona NA, Verdugt, the Netherlands) and Ca (Calprona $\mathrm{C} / \mathrm{CA}$, Verdugt) salts containing 76 and $78 \%$ propionate, respectively. The mash of ingredients was not conditioned with steam before pelleting. Soyhulls were used because of their ease of pelleting. The addition of por- 
Table 1. Ingredient composition of basal diets. ${ }^{1}$

\begin{tabular}{|c|c|c|c|}
\hline Ingredient & $\begin{array}{l}-21 \text { to } \\
0 \text { DIM }\end{array}$ & $\begin{array}{l}1 \text { to } \\
21 \text { DIM }\end{array}$ & $\begin{array}{l}22 \text { to } \\
70 \mathrm{DIM}^{2}\end{array}$ \\
\hline & \multicolumn{3}{|c|}{$\%$ of diet DM } \\
\hline Brome grass hay & 17.3 & - & - \\
\hline Alfalfa hay & 17.5 & 15.1 & 12.7 \\
\hline Alfalfa haylage & - & 11.3 & 11.8 \\
\hline Corn silage, processed & 37.0 & 25.3 & 26.5 \\
\hline Whole cottonseed & 3.3 & 7.9 & 6.6 \\
\hline Wet distillers grain & - & 6.9 & 6.9 \\
\hline Dried distillers grain & 1.7 & - & - \\
\hline Corn, high moisture & - & 12.1 & 16.4 \\
\hline Corn grain, ground & 12.7 & 8.5 & 7.1 \\
\hline Soybean meal, $44 \%$ & & 5.8 & 4.8 \\
\hline SoyChlor $16-7^{3}$ & 7.7 & - & - \\
\hline SoyPlus $^{3}$ & - & 3.04 & 2.53 \\
\hline Megalac- $R^{4}$ & - & - & 1.25 \\
\hline Limestone & 1.34 & 1.23 & 1.03 \\
\hline Sodium bicarbonate & - & 0.75 & 0.63 \\
\hline Fish meal, menhaden & - & 0.54 & 0.42 \\
\hline Pork meat and bone meal & - & 0.50 & 0.42 \\
\hline Yeast culture ${ }^{5}$ & 0.40 & 0.24 & 0.20 \\
\hline Magnesium oxide & - & 0.22 & 0.18 \\
\hline Salt & - & 0.22 & 0.18 \\
\hline Vitamin $A, D$, and E premix & $0.65^{\mathrm{a}}$ & $0.28^{b}$ & $0.23^{b}$ \\
\hline Urea & 0.18 & - & - \\
\hline $4-\mathrm{Plex}^{6}$ & 0.07 & 0.06 & 0.05 \\
\hline Vitamin E premix $^{7}$ & 0.11 & 0.04 & 0.04 \\
\hline
\end{tabular}

\footnotetext{
${ }^{1}$ Treatments applied as topdressed ingredients (fed from $14 \mathrm{~d}$ prepartum to 21 DIM) were (kg/d, DM basis): Control (CS): 0.32 cornstarch; propionate (PRO): 0.73 soyhull-propionate pellet +0.21 cornstarch; propionate + fat 1 (PF1): 0.73 soyhull-propionate pellet +0.13 LCFA; and propionate + fat 2 (PF2): 1.08 soyhull-propionate pellet +0.19 LCFA.

${ }^{2}$ All cows were fed the same diet from 22 to 70 DIM.

${ }^{3}$ West Central Soy, Ralston, IA.

${ }^{4}$ Church and Dwight Co., Princeton, NJ.

${ }^{5}$ Diamond V XP, Diamond V Mills, Inc., Cedar Rapids, IA.

${ }^{6} 4$-Plex, Zinpro Corp., Eden Prairie, MN.

${ }^{7}$ Contains 44,092 IU of vitamin E per $\mathrm{kg}$.

${ }^{\mathrm{a} C}$ Contains $1856 \mathrm{IU}$ of vitamin A, 465 IU vitamin D, and $18 \mathrm{IU}$ of vitamin $\mathrm{E}$ per $\mathrm{kg}$.

${ }^{\mathrm{b}}$ Contains 2,727,118 IU of vitamin A, 544,541 IU vitamin D, and 10,908 IU of vitamin E per kg.
}

cine choice white grease was necessary to reduce die friction and optimize pellet quality. In addition, pelleting the soyhulls and propionate provided a homogeneous mixture to ensure consistent delivery of propionate to assigned treatments. The final pelleted product contained $21.1 \%$ salts of propionate, $69.5 \%$ soyhulls, $3.2 \%$ porcine choice white grease, $3.1 \% \mathrm{Na}$, and $3.1 \%$ $\mathrm{Ca}$ on a DM basis. Nutrient analyses of the soyhullpropionate pellet were: $85.9 \% \mathrm{DM}, 8.8 \% \mathrm{CP}, 32.0 \%$ $\mathrm{ADF}, 42.8 \% \mathrm{NDF}, 3.9 \%$ ether extract, $0.11 \% \mathrm{P}, 1.17 \%$ $\mathrm{K}$, and $0.17 \% \mathrm{Mg}$ on a $\mathrm{DM}$ basis.

Cows were housed on a wheat-straw bedded pack prepartum and in a free-stall barn during the postpartal phase of the experiment. Diets were mixed and fed daily at $0600 \mathrm{~h}$ for ad libitum consumption using the Calan Broadbent feeding system (American Calan, Inc.,
Northwood, NH). All diets were offered as a TMR. Weighbacks were measured, recorded, and discarded before feeding each day and amounts fed were adjusted to ensure a $10 \%$ feed refusal. Samples of TMR were collected weekly for analysis. Body weights and BCS (1 to 5 in 0.25 increments; Wildman et al., 1982) were recorded on 2 consecutive days, $4 \mathrm{~h}$ after feeding on $\mathrm{d}$ 21 before expected calving, at parturition, and at 21 DIM. The same 3 individuals recorded BCS during the entire experiment. In addition, calf birth weights and calving difficulty scores were recorded $(1=$ no problem; $2=$ slight problem; $3=$ needed assistance $4=$ consider able force; $5=$ caesarian). Cows were milked at 0600 , 1400 , and $2100 \mathrm{~h}$, and milk yields were recorded. Milk samples were collected on d 7, 14, and 21 of lactation from all 3 milkings each day. Samples were composited by day and analyzed for protein, fat, lactose, MUN, and SCC. Solids-not-fat was calculated. Incidences of milk fever, metritis, displaced abomasum, mastitis, and foot ailments were also recorded during the experiment.

Target day and actual day of blood sampling relative to calving were -14 and $-13.7(\mathrm{SD}=2.1),-7$ and -7.1 $(\mathrm{SD}=1.6),-2$ and $-2.4(\mathrm{SD}=1.0), 2$ and $2.0(\mathrm{SD}=0.6)$, 7 and $7.1(\mathrm{SD}=1.0), 14$ and $14.0(\mathrm{SD}=1.6)$, and 21 and $21.0(\mathrm{SD}=1.0)$, respectively. Approximately $4 \mathrm{~h}$ after feeding, blood was sampled from a coccygeal vessel into 2 evacuated tubes (Becton Dickinson and Co., Franklin Lakes, NJ) containing K-EDTA and sodium fluoride. Samples were immediately placed on ice and transported to the laboratory where they were centrifuged $(500 \times g)$ and plasma was harvested and stored at $-20^{\circ} \mathrm{C}$ until further analysis.

\section{Laboratory Analysis}

Samples of diets were dried at $55^{\circ} \mathrm{C}$ in a forced-air oven and allowed to air-equilibrate before being ground to pass a 2-mm screen of a standard Wiley mill (model 3; Arthur H. Thomas Co., Philadelphia, PA). Samples were composited by diet (prepartum and postpartum) and month and analyzed for $\mathrm{DM}$ at $105^{\circ} \mathrm{C}$ for $24 \mathrm{~h}, \mathrm{CP}$ (AOAC, 1997) using a LECO-428 combustion analyzer (LECO Corp., St. Joseph, MI), NDF (Van Soest et al., 1991), ether extract (AOAC, 1997), minerals (AOAC, 1997; 985.01), and ADF and lignin (AOAC, 1997). Neutral detergent fiber and $\mathrm{ADF}$ were measured using the ANKOM A200 (ANKOM Technology Corp., Fairport, NY) filter bag technique. Determinations of ADF were according to AOAC (973.18 C, 1997) and NDF was according to Van Soest et al. (1991) with the addition of $4 \mathrm{~mL}$ of $\alpha$-amylase and $20 \mathrm{~g}$ of sodium sulfite. Starch was measured as dextrose after treating samples with glucoamylase using a YSI 2700 SELECT Biochemistry Analyzer (Application Note \#319, Yellow Springs, OH). 
Table 2. Nutrient composition ${ }^{1}$ (DM basis) of control (CS), propionate (PRO), propionate + fat 1 (PF1), and propionate + fat 2 (PF2).

\begin{tabular}{|c|c|c|c|c|c|c|c|c|c|}
\hline \multirow[b]{2}{*}{ Nutrient } & \multicolumn{4}{|c|}{-14 to $0 \mathrm{DIM}$} & \multicolumn{4}{|c|}{1 to $21 \mathrm{DIM}$} & \multirow{2}{*}{$\begin{array}{l}22 \text { to } \\
70 \mathrm{DIM}^{2}\end{array}$} \\
\hline & $\mathrm{CS}$ & PRO & PF1 & $\mathrm{PF} 2$ & CS & PRO & PF1 & PF2 & \\
\hline DM, \% as fed & 49.7 & 49.7 & 49.7 & 49.9 & 52.8 & 52.8 & 52.8 & 52.9 & 49.0 \\
\hline $\mathrm{CP}, \%$ & 14.7 & 14.4 & 14.3 & 14.0 & 19.4 & 18.8 & 18.7 & 18.3 & 18.1 \\
\hline NEL, ${ }^{3} \mathrm{Mcal} / \mathrm{kg}$ & 1.53 & 1.51 & 1.54 & 1.56 & 1.64 & 1.63 & 1.65 & 1.66 & 1.64 \\
\hline $\mathrm{ADF}, \%$ & 26.4 & 27.2 & 27.2 & 27.2 & 21.2 & 21.8 & 21.8 & 22.0 & 20.6 \\
\hline NDF, \% & 38.4 & 39.3 & 39.2 & 39.1 & 31.5 & 32.2 & 32.1 & 32.3 & 30.8 \\
\hline $\mathrm{NFC}, 4 \%$ & 34.5 & 33.9 & 33.2 & 33.0 & 36.5 & 36.5 & 36.0 & 35.8 & 37.6 \\
\hline Ether extract, \% & 4.1 & 4.1 & 5.0 & 5.4 & 4.6 & 4.5 & 5.2 & 5.5 & 6.3 \\
\hline Ash, \% & 8.3 & 8.3 & 8.3 & 8.5 & 8.0 & 8.0 & 8.0 & 8.1 & 7.2 \\
\hline $\mathrm{Ca}, \%$ & 1.40 & 1.58 & 1.68 & 1.78 & 1.35 & 1.45 & 1.53 & 1.61 & 1.19 \\
\hline $\mathrm{P}, \%$ & 0.39 & 0.37 & 0.37 & 0.35 & 0.47 & 0.45 & 0.45 & 0.43 & 0.42 \\
\hline $\mathrm{Mg}, \%$ & 0.49 & 0.47 & 0.47 & 0.46 & 0.49 & 0.47 & 0.47 & 0.46 & 0.44 \\
\hline $\mathrm{K}, \%$ & 1.25 & 1.26 & 1.26 & 1.25 & 1.46 & 1.44 & 1.44 & 1.43 & 1.24 \\
\hline $\mathrm{Na}, \%$ & 0.16 & 0.37 & 0.36 & 0.47 & 0.35 & 0.50 & 0.50 & 0.57 & 0.31 \\
\hline $\mathrm{Cl}, \%$ & 1.08 & 1.02 & 1.02 & 0.98 & 0.45 & 0.42 & 0.42 & 0.41 & 0.37 \\
\hline $\mathrm{S}, \%$ & 0.24 & 0.23 & 0.23 & 0.22 & 0.26 & 0.25 & 0.25 & 0.24 & 0.22 \\
\hline $\mathrm{DCAD},{ }^{5} \mathrm{mEq} / \mathrm{kg}$ of $\mathrm{DM}$ & -62 & 55 & 49 & 108 & 238 & 313 & 310 & 347 & 210 \\
\hline
\end{tabular}

\footnotetext{
${ }^{1}$ Includes topdressed ingredients. Values are based upon nutrient analyses of basal diets and topdressed ingredients and actual mean DMI by treatment.

${ }^{2}$ All cows were fed the same diet from 22 to 70 DIM.

${ }^{3}$ Calculated using NRC (2001).

${ }^{4} \mathrm{NFC}=100-(\% \mathrm{NDF}+\% \mathrm{CP}+\%$ Ether extract $+\%$ Ash $)$.

${ }^{5} \mathrm{DCAD}=$ Dietary cation-anion difference, as $[(\mathrm{Na}+\mathrm{K})-(\mathrm{Cl}+\mathrm{S})]$ in milliequivalents per kilogram of DM.
}

Minerals were quantified according to AOAC methods (985.01, 1997) using an inductively coupled plasma spectrometer (Thermo Garrell Ash, Franklin, MA).

Milk compositional analysis was conducted by Heart of America DHI Laboratory (Manhattan, KS) according to approved procedures of AOAC (1990). Milk true protein, fat, and lactose were determined using near infrared spectroscopy (Bentley 2000 Infrared Milk Analyzer, Bentley Instruments, Chaska, MN). Concentration of MUN was determined using chemical methodology based on a modified Berthelot reaction (ChemSpec 150 Analyzer, Bentley Instruments), and somatic cells were counted using a flow cytometer laser (Somacount 500, Bentley Instruments).

Plasma samples were thawed and concentrations of glucose were determined using glucose oxidase (Sigma Kit \#315, Sigma Diagnostics, St. Louis, MO) according to the procedures of Trinder (1969). Concentration of BHBA in plasma was determined (Pointe Scientific, Inc., Lincoln Park, MI) following the methods of Wil-

Table 3. Previous 305-d mature-equivalent (305-d ME) milk, days on treatment, BW, BCS, calf birth weights, calving difficulty, and prepartum DMI of cows fed control (CS), propionate (PRO), propionate + fat 1 (PF1), and propionate + fat 2 (PF2).

\begin{tabular}{|c|c|c|c|c|c|c|c|c|}
\hline \multirow[b]{2}{*}{ Item } & \multicolumn{4}{|c|}{ Diet } & \multirow[b]{2}{*}{ SEM } & \multicolumn{3}{|c|}{$\begin{array}{c}\text { Contrast }^{1} \\
P=\end{array}$} \\
\hline & $\mathrm{CS}$ & PRO & PF1 & PF2 & & 1 & 2 & 3 \\
\hline Number of cows & 10 & 10 & 10 & 10 & - & - & - & - \\
\hline Previous 305-d ME, kg & 11,732 & 10,975 & 12,452 & 12,063 & 396 & 0.83 & 0.01 & 0.49 \\
\hline Days on treatment & 36.8 & 35.8 & 34.3 & 36.0 & 1.36 & 0.35 & 0.48 & 0.38 \\
\hline $\mathrm{BW},{ }^{2,3} \mathrm{~kg}$ & 772 & 776 & 763 & 741 & 19 & 0.62 & 0.66 & 0.42 \\
\hline $\mathrm{BCS}^{3, \mathrm{a}}$ & 3.37 & 3.41 & 3.40 & 3.20 & 0.11 & 0.77 & 0.95 & 0.19 \\
\hline Calf BW, kg & 47.5 & 47.8 & 49.0 & 43.2 & 3.8 & 0.50 & 0.19 & 0.02 \\
\hline Calving difficulty ${ }^{4}$ & 1.6 & 1.8 & 2.6 & 1.3 & 0.38 & 0.85 & 0.85 & 0.31 \\
\hline DMI, kg/d & 11.3 & 11.9 & 12.2 & 12.1 & 0.99 & 0.52 & 0.80 & 0.91 \\
\hline
\end{tabular}

\footnotetext{
${ }^{1}$ Contrasts: $1=$ CS vs. all other diets, $2=$ PRO vs. PF1, $3=$ PF1 vs. PF2.

${ }^{2}$ Measured $21 \mathrm{~d}$ before expected calving.

${ }^{3}$ Wildman et al., 1982.

${ }^{4}$ Five-point scale: 1 = no assistance, 2 = slight problem, 3 = needed assistance, $4=$ considerable force, and $5=$ caesarian.
} 
liamson et al. (1962) and plasma NEFA concentrations were determined using a colorimetric assay (NEFA-C Kit, Wako Chemicals, Richmond, VA), following modifications by Johnson and Peters (1993). Insulin was quantified by solid-phase radioimmunoassay (Coat-ACount, Diagnostic Products Corp., Los Angeles, CA) with an intraassay CV of $1.5 \%$.

\section{Statistical Analyses}

Two cows suffered displaced abomasums: 1 fed CS at 10 DIM and 1 fed PF1 at 15 DIM. Both cows were surgically treated and continued on trial. Dry matter intake collected during their recovery period ( $1 \mathrm{wk}$ ) was excluded from the data set. Two cows suffered from foot ailments that subsequently affected their DMI. Data from one of those cows (fed PF1) was already excluded due to its abomasal displacement. Feed intake data from 15 to 21 DIM were excluded from the second cow (fed CS). Among the cows remaining, 6 were treated for metritis, 2 for ketosis, and 2 for mastitis. Effects of treatments on incidences of health disorders were not analyzed for statistical differences because of insufficient replication; however, all cows experiencing disorders were included in the data set, excluding those aforementioned.

The experiment was a randomized block design based upon expected calving date. Milk yield and DMI data were reduced to weekly means for statistical analysis. Milk production data collected on the day of calving was not included in the data set because of the inherent difficulties associated with data collected on the day of calving. Data were analyzed as repeated measures using PROC MIXED (Littell et al., 1996) of SAS software, version 8.1 (SAS Institute, 1999). For each variable, cow was subjected to 4 covariance structures: autoregressive order 1, Toeplitz, variance component, and compound symmetry. The structure yielding the largest Akaike's information criteria was used. For variables measured over time, the model included treatment, time (week or day depending on the variable), and 2way interactions as fixed effects. The random effect was diet nested within cow. The method of Kenward-Rogers was used for calculation of denominator degrees of freedom for $F$-tests. Covariates of initial BW and BCS, days on treatment, and previous 305-d mature equivalent milk yield were included for all data sets. Covariates and interactions were dropped from the model one at time, starting with the least significant, and continuing until all remaining variables were significant. Prepartal and postpartal data were analyzed separately. Preplanned contrasts were 1) CS vs. PRO, PF1, and PF2; 2) PRO vs. PF1; and 3) PF1 vs. PF2. The purpose of comparing CS vs. all other dietary treatments was to test the effect of glucogenic supplementation, regardless of type or amount. The PRO vs. PF1 contrast was used to determine the effect of feeding propionate with or without supplemental fat. The contrast of PF1 vs. PF2 was useful in determining if the combination of propionate and fat was dependent upon amount fed. Least squares means and standard errors of means are reported. Treatment effects at specific days were determined by use of the PDIFF option within the LSMEANS statement. Statistical significance was declared at $P<0.05$, with trends noted at $0.05<P \leq 0.15$.

\section{RESULTS}

Ingredient and nutrient composition of diets are shown in Tables 1 and 2, respectively. Crude protein decreased and ether extract increased with the addition of propionate and LCFA to PRO, PF1, and PF2. As expected, the addition of $\mathrm{Na}$ and $\mathrm{Ca}$ salts of propionate increased diet $\mathrm{Ca}$ and $\mathrm{Na}$ both pre- and postpartum. The greatest concentration of ether extract (PF2 at 5.5\% of diet DM) was formulated and analyzed to be less than the maximal dietary level of 6 to $7 \%$ of diet DM recommended by NRC (2001). The LCFA source was assayed and found to contain $94.6 \% \mathrm{DM}, 0.82 \% \mathrm{CP}$, $1.7 \% \mathrm{ADF}, 3.7 \% \mathrm{NDF}, 81.6 \%$ fat via acid-hydrolysis, $9.66 \% \mathrm{Ca}, 0.01 \% \mathrm{P}, 0.13 \% \mathrm{~K}$, and $0.09 \% \mathrm{Mg}$ on a $\mathrm{DM}$ basis. Diets were formulated according to recommendations by NRC (2001) using a BW of $650 \mathrm{~kg}$ and targeted DMI of $12.9,21.4$, and $25.6 \mathrm{~kg} / \mathrm{d}$ for pre-, postpartum, and high group (22 to 70 DIM) phases of the experiment.

Cows used in this study are described in Table 3. Average previous 305-d mature equivalent milk yield was $11,805 \mathrm{~kg}$ for all treatments. Previous $305-\mathrm{d}$ mature equivalent yield was greater $(P \leq 0.01)$ for cows fed PF1 relative to cows fed PRO. Therefore, when appropriate, previous 305-d milk yield was included as a covariate during statistical analysis of data. Days on treatment were similar among treatments and averaged $35.7 \pm 1.4 \mathrm{~d}$. Calf birth weights were greater $(P \leq$ 0.02) for cows fed PF1 relative to those fed PF2; however, calving difficulty scores were similar among treatments. Average prepartum DMI was not affected by diet. With the exception of cows fed PF2, DMI decreased for all treatments from wk 2 to wk 1 prepartum (Figure 1).

Average DMI (Table 4) during the first 21 DIM was $16.4 \mathrm{~kg} / \mathrm{d}$ and did not differ among treatments; however, a diet $\times$ week interaction $(P \leq 0.02)$ for postpartal DMI was observed as cows fed PF2 consumed $2 \mathrm{~kg} / \mathrm{d}$ less DM during wk 2 relative to other treatments (Figure 1). Milk (Figure 2) and energy-corrected milk (ECM; Orth, 1992) yields were unaffected by dietary treatments. Actual 305-d milk yield (Table 4) averaged 


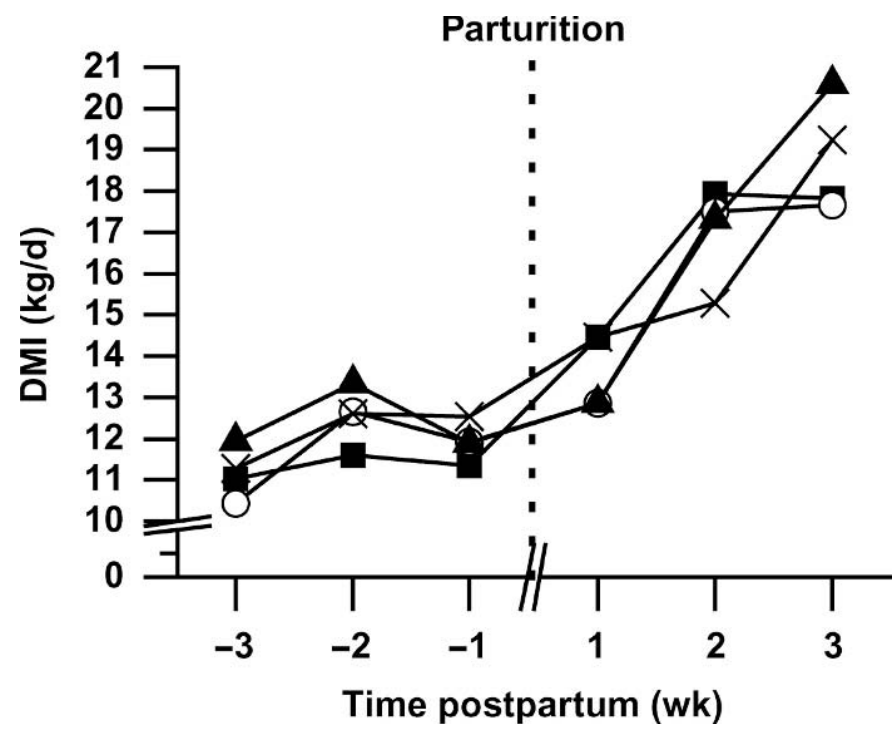

Figure 1. Dry matter intake (pooled SEM = 1.34) of cows fed cornstarch (control; $\mathbf{\square})$, propionate $(\bigcirc)$, propionate + fat level $1(\mathbf{\Lambda})$, and propionate + fat level $2(\times)$. There was a diet $\times$ week interaction $(P=0.02)$ for DMI.

$12,931 \mathrm{~kg}$ and was not different among treatments. Feed conversion (ECM/DMI) tended $(P \leq 0.13)$ to be greater for cows fed PRO compared with those fed PF1. Cows fed PRO tended $(P \leq 0.10)$ to yield more milk fat than did those fed PF1 (1.58 vs. $1.29 \mathrm{~kg} / \mathrm{d}$, respectively). Percentage true protein in milk was greater for cows fed CS relative to all other treatments $(P \leq 0.04,3.31$ vs. $3.16 \%$, respectively). A similar effect of treatments

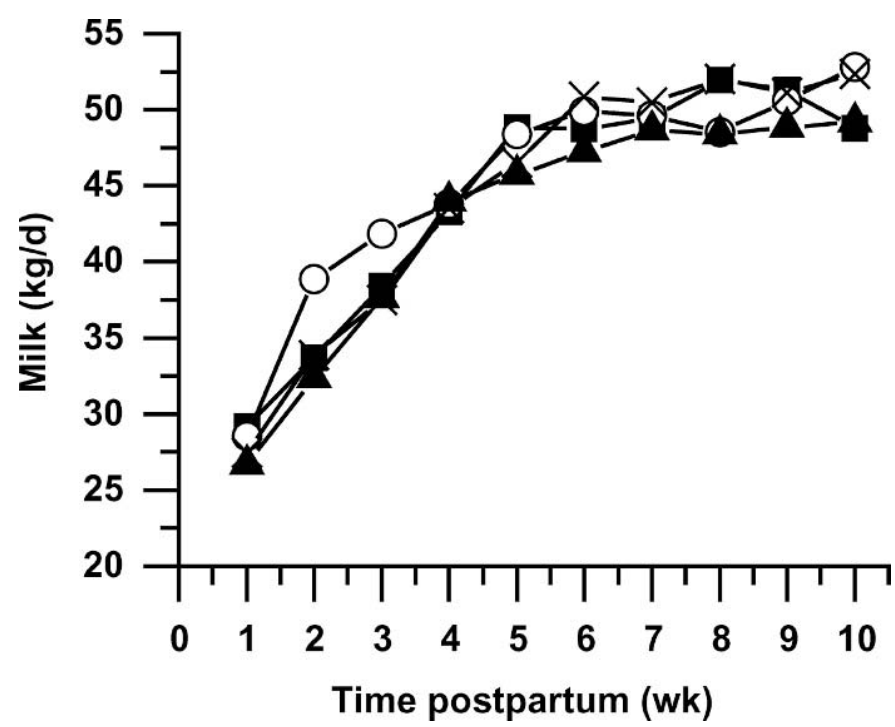

Figure 2. Milk yield (pooled SEM = 1.20) of cows fed cornstarch (control; $\mathbf{\square}$ ), propionate $(\bigcirc)$, propionate + fat level $1(\mathbf{\Delta})$, and propionate + fat level $2(\times)$. was observed for milk solids-not-fat, as percentages were greater for cows fed CS than the average of those fed PRO, PF1, and PF2 ( $P \leq 0.05,9.01$ vs. $8.82 \%$, respectively). Feeding CS decreased MUN compared with other treatments $(P \leq 0.04,12.5$ vs. $14.4 \mathrm{mg} / \mathrm{dL}$, respectively). In addition, MUN was greater for cows fed PF2 relative to cows fed $\mathrm{PF} 1$ ( $P \leq 0.02,16.4$ vs. $13.8 \mathrm{mg} / \mathrm{dL}$, respectively). Although BW were similar 3 wk before parturition (Table 3), BW tended to be greater for cows fed CS at 21 DIM relative to all other treatments $(P \leq$ $0.15,678$ vs. $654 \mathrm{~kg}$, respectively).

Effects of treatments on plasma glucose and insulin are presented in Table 5 and plotted over time in Figure 3. Overall, concentrations of plasma glucose and insulin were not different among treatments; however, differences were observed on specific days relative to calving. Concentrations of glucose in plasma of cows fed PF2 tended to be lower than for cows fed PF1 at $7 \mathrm{~d}$ before parturition (Figure 3A, $P \leq 0.06,72.0$ vs. $80.8 \mathrm{mg} / \mathrm{dL}$, respectively). At $14 \mathrm{~d}$ before parturition, concentrations of insulin in plasma of cows fed PRO or PF2 were 2fold greater than those fed PF1 (Figure 3B, $P \leq 0.06,211$ and 202 vs. $95 \mathrm{pg} / \mathrm{mL}$, respectively). Similarly, plasma insulin concentrations of cows fed PF2 and CS tended to be greater than for cows fed PF1 at $14 \mathrm{~d}$ prepartum (Figure 3B, $P \leq 0.08,202$ and 211 vs. $95 \mathrm{pg} / \mathrm{mL}$, respectively).

Effects of treatments on plasma NEFA and BHBA are shown in Table 5 and Figure 4. Concentrations of NEFA in plasma increased prepartum for cows fed CS, PRO, and PF1 and were lower $(P \leq 0.05) 2 \mathrm{~d}$ before parturition for PF2 compared with PF1 (759 vs. 426 $\mu \mathrm{Eq} / \mathrm{L}$, respectively). Overall, concentrations of NEFA in plasma averaged $623 \mu \mathrm{Eq} / \mathrm{L}$ and tended to be lower in cows fed PF2 compared with those fed PF1 $(P \leq 0.07$, 675 vs. $515 \mu \mathrm{Eq} / \mathrm{L}$, respectively). More importantly, concentrations of NEFA in plasma were greater during the first 21 DIM for cows fed PF1 relative to those fed PF2 $(P \leq 0.02,623$ vs. $873 \mu \mathrm{Eq} / \mathrm{L}$, respectively). The difference in NEFA was particularly evident at 2 DIM as concentrations of NEFA in plasma of cows fed PF1 were 2 -fold greater than cows fed PF2 $(P<0.01,552$ vs. $1111 \mu \mathrm{Eq} / \mathrm{L}$, respectively). Effects of treatments on NEFA in plasma did not translate into differences in concentrations of BHBA in plasma which were unaffected by dietary treatments.

\section{DISCUSSION}

A glucose deficit, estimated at $500 \mathrm{~g} / \mathrm{d}$ (Drackley et al., 2001) is typical of the early postpartal period of the lactation cycle. Failure to address this metabolic challenge results in early postpartal health disorders, compromised lactation, and potential mortality. The 
Table 4. Postpartum DMI, milk yield, milk composition, milk SCC, BW, and BCS of cows fed control (CS), propionate (PRO), propionate + fat 1 (PF1), and propionate + fat $2(\mathrm{PF} 2)$.

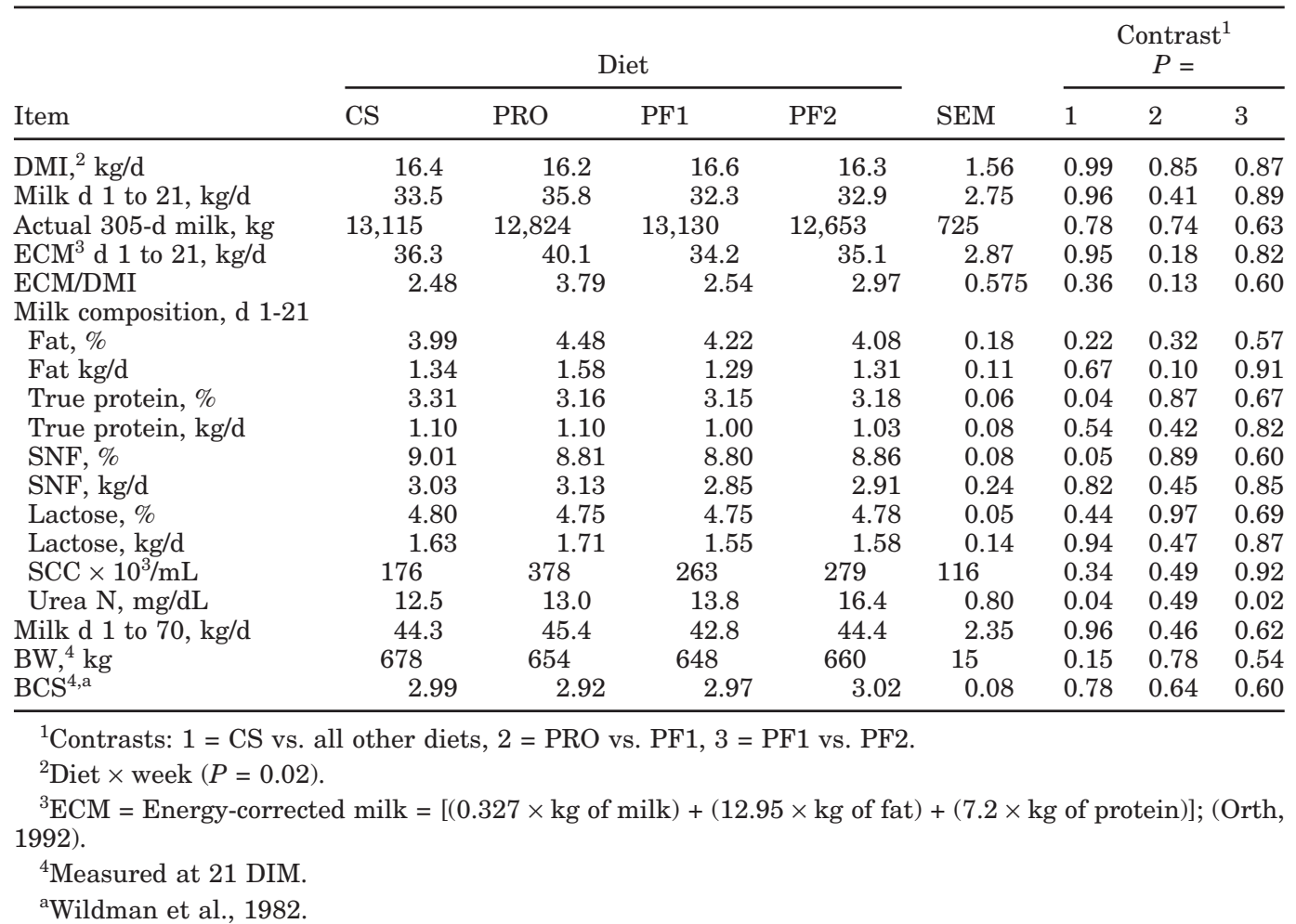

objective of feeding glucose precursors is to alleviate this glucose deficit. Several studies document the effects of feeding propionate or fat either pre- (Grum et al., 1996; Beem, 2003) or postpartum (Schultz, 1958; Jerred et al., 1990); however, only one experiment (Pat- ton et al., 2004) described the effects of supplementing these ingredients both prepartum and postpartum.

Minimizing prepartal feed intake depression is recommended (Grummer, 1995) as the focal point of the transition cow management. For any feed supplement

Table 5. Plasma glucose, insulin, NEFA, and BHBA of cows fed control (CS), propionate (PRO), propionate + fat 1 (PF1), and propionate + fat 2 (PF2).

\begin{tabular}{|c|c|c|c|c|c|c|c|c|}
\hline \multirow[b]{2}{*}{ Item } & \multicolumn{4}{|c|}{ Diet } & \multirow[b]{2}{*}{ SEM } & \multicolumn{3}{|c|}{$\begin{array}{c}\text { Contrast }^{1} \\
P=\end{array}$} \\
\hline & CS & PRO & PF1 & PF2 & & 1 & 2 & 3 \\
\hline \multicolumn{9}{|c|}{ Glucose, mg/dL } \\
\hline All data & 73.3 & 71.8 & 72.2 & 70.6 & 2.0 & 0.48 & 0.64 & 0.54 \\
\hline Prepartum & 80.8 & 81.2 & 81.3 & 77.2 & 2.49 & 0.74 & 0.72 & 0.29 \\
\hline Postpartum & 67.7 & 64.5 & 65.2 & 65.2 & 2.46 & 0.36 & 0.40 & 0.87 \\
\hline \multicolumn{9}{|l|}{ Insulin, $\mathrm{pg} / \mathrm{mL}$} \\
\hline All data & 96.1 & 98.0 & 82.4 & 99.4 & 15.1 & 0.87 & 0.47 & 0.43 \\
\hline Prepartum & 134.5 & 141.4 & 95.2 & 146.2 & 29.6 & 0.84 & 0.31 & 0.22 \\
\hline Postpartum & 69.4 & 65.8 & 71.3 & 63.9 & 8.7 & 0.79 & 0.65 & 0.53 \\
\hline \multicolumn{9}{|l|}{$\mathrm{NEFA}, \mu \mathrm{Eq} / \mathrm{L}$} \\
\hline All data & 633 & 668 & 675 & 515 & 62 & 0.85 & 0.93 & 0.07 \\
\hline Prepartum & 383 & 579 & 414 & 377 & 92 & 0.49 & 0.24 & 0.77 \\
\hline Postpartum & 810 & 720 & 873 & 623 & 82 & 0.43 & 0.18 & 0.02 \\
\hline \multicolumn{9}{|l|}{ BHBA, mg/dL } \\
\hline All data & 8.43 & 8.99 & 7.50 & 7.13 & 1.57 & 0.76 & 0.51 & 0.87 \\
\hline Prepartum & 3.75 & 3.49 & 3.32 & 3.64 & 0.27 & 0.37 & 0.25 & 0.32 \\
\hline Postpartum & 12.07 & 13.55 & 10.53 & 10.02 & 2.74 & 0.82 & 0.44 & 0.89 \\
\hline
\end{tabular}

${ }^{1}$ Contrasts: 1 = CS vs. all other diets, $2=$ PRO vs. PF1, $3=$ PF1 vs. PF2. 


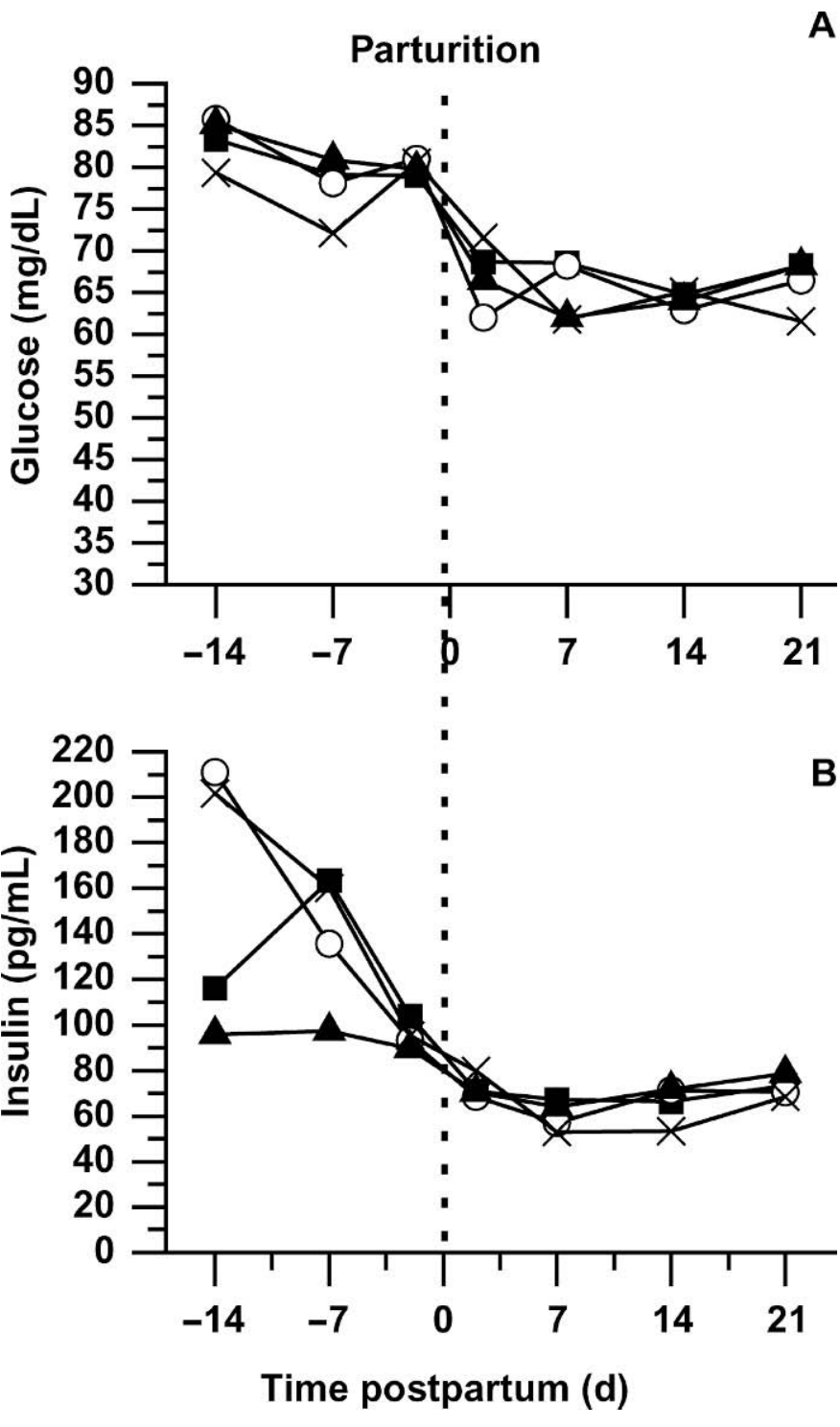

Figure 3. Plasma glucose (A) and insulin (B) concentrations (pooled SEM = 3.43 and 20.9, respectively) of cows fed cornstarch (control; $\mathbf{D})$, propionate $(\bigcirc)$, propionate + fat level $1(\mathbf{\Lambda})$, and propionate + fat level $2(x)$.

to be effective as a glucose precursor, feed intake should not be depressed because prepartal DMI is inversely related to concentrations of NEFA and BHBA in plasma and liver triglycerides (Bertics et al., 1992). In the study under discussion, feeding propionate with or without LCFA did not significantly affect DMI. An exhaustive review by Allen (2000) found LCFA to decrease DMI $2.5 \%$ for each percentage unit of added Ca salts of palm fatty acids in the diet over control. Accordingly, we should have observed a decrease in DMI of nearly $3 \%$ pre- and postpartum for cows fed PF1 and PF2. According to Allen (2000), these decreases were likely to

A

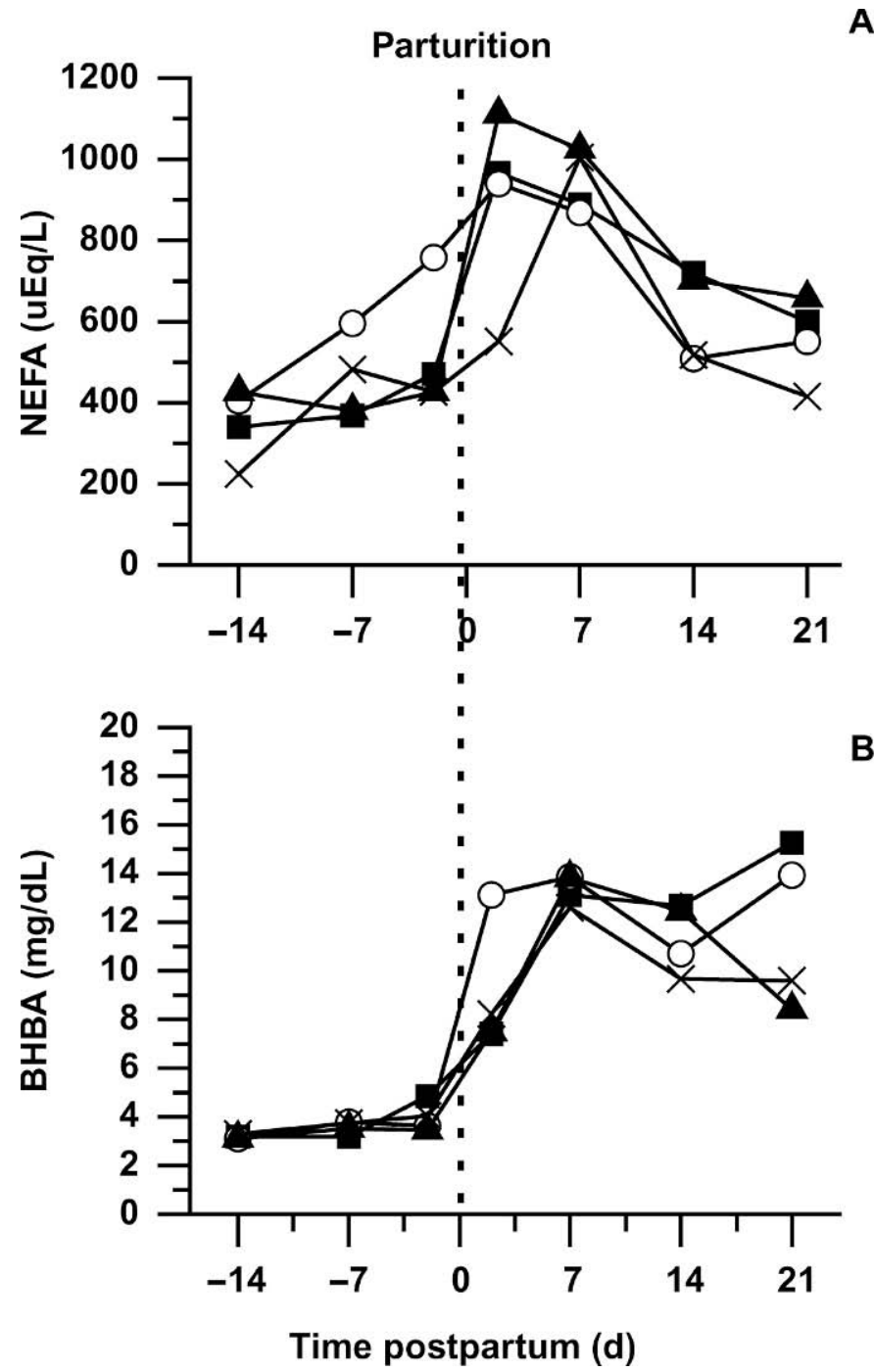

Figure 4. Plasma NEFA (A) and BHBA (B) concentrations (pooled $\mathrm{SEM}=126$ and 1.86, respectively) of cows fed cornstarch (control; 口), propionate $(\bigcirc)$, propionate + fat level $1(\boldsymbol{\Lambda})$, and propionate + fat level $2(x)$.

be minimized by hand mixing the LCFA into the TMR vs. applied as a top dress. Dry matter intake was decreased prepartum (Grum et al., 1996) and postpartum (Jerred et al., 1990) when fat was fed at greater levels ( 0.6 and $1.1 \mathrm{~kg} / \mathrm{d}$, respectively) than those used in the present study. We intended to supply sufficient Ca salts of fatty acids without negatively affecting DMI. These data indicate that DMI of cows fed 93 or $154 \mathrm{~g} / \mathrm{d}$ fat as $\mathrm{Ca}$ salts was not negatively affected compared with cows fed a control diet free of supplemental fat, especially DMI of cows fed $154 \mathrm{~g} / \mathrm{d}$ during the week before parturition (Figure 1).

Effects of feeding propionate on DMI are limited because most reports were field studies or were conducted 
using propionate-based drenches in combination with pen research. Beem (2003) recently fed Ca-propionate at $113 \mathrm{~g} / \mathrm{d}$ for $21 \mathrm{~d}$ before expected calving and found no effect on DMI. Although we fed greater amounts of propionate (120 and $178 \mathrm{~g} / \mathrm{d}$ for PF1 and PF2, respectively), our results are in agreement with those of Beem (2003). The possibility of observing a decrease in DMI in cows fed PRO was likely because ruminal infusions of propionate are known to elicit hypophagia via effects on both satiety and hunger (Oba and Allen, 2003). Because DMI of cows fed propionate alone (PRO) or combinations of propionate and LCFA (PF1 and PF2) were similar to cows fed CS, it is doubtful that the amounts of propionate fed in this study elicited hypophagic effects as reported by Oba and Allen (2003); however, it should be noted that these effects may have decreased DMI of cows fed the greater quantity of propionate found in PF2 during the second week of lactation.

Similar to Patton et al. (2004), results reported here of feeding propionate in combination with LCFA did not affect yield of milk or ECM. Milk fat yields $(\mathrm{kg} / \mathrm{d})$ and yields of ECM per kg of DMI tended to be greater in cows fed PRO relative to cows fed PF1. Similar to our results, the addition of LCFA has increased production efficiency when fed at $0.5 \mathrm{~kg} / \mathrm{d}$ (Canale et al., 1990). Because DMI was similar between cows fed PRO and $\mathrm{PF} 1$, one could argue that cows fed PF1 were experiencing less of a negative energy balance and therefore mobilizing less tissue; however, concentrations of NEFA in plasma do not support this claim as plasma NEFA were numerically greater $(P \leq 0.18)$ for cows fed PF1. According to Rigout et al. (2003), a negative relationship exists between milk fat yield and energy provided by glucogenic precursors $\left(R^{2}=0.89\right)$ and one can expect a $0.14 \%$ decrease in milk fat for every $1 \mathrm{Mcal}$ of glucose precursor ingested. Using the energy value of 0.233 $\mathrm{Mcal} / \mathrm{mole}$ of propionate from Rigout et al. (2003), cows fed propionate (PRO, PF1, PF2) ingested 0.62, 0.62, and $0.92 \mathrm{Mcal}$ of glucose precursor, respectively. Based on these calculations, a 0.09, 0.09, and 0.13\% (PRO, PF1, PF2) decrease in milk fat would be expected, but was not observed.

The greater milk protein percentage and solids-notfat of cows fed CS relative to cows fed all other diets may be attributable to the greater dietary CP supply (19.4 vs. $18.6 \%$, respectively, Table 3 ) in combination with a highly fermentable carbohydrate (topdress of $0.32 \mathrm{~kg} / \mathrm{d}$ of cornstarch). Treatments did not affect DMI suggesting the decrease in milk protein percentage and greater MUN could be attributed to effects of propionate or LCFA on ruminal $\mathrm{pH}$ and fermentation profiles, and therefore microbial protein synthesis and outflow to the intestine. Hoover and Stokes (1991) indicated the rate of ruminal carbohydrate digestion is critical in de- termining the energy available for microbial growth. Our aim was to supply propionate and Ca salts of fatty acids to improve the energy status of the peripartum dairy cow; however, these ingredients do not necessarily contribute to the energy pool of the rumen. Grummer (1988) fed $680 \mathrm{~g} / \mathrm{d}$ of LCFA, 3 times the quantity used in this experiment, and observed no effect on ruminal $\mathrm{pH}$, total VFA, or VFA profiles and a decrease $(0.13$ percentage units; $P<0.06$ ) in milk protein. Canale et al. (1990) fed 0 or $0.5 \mathrm{~kg} / \mathrm{cow}$ per d of LCFA and observed a decrease in milk protein percentage from 3.10 to $3.03 \%(P<0.01)$. Our results concur with those of Grummer (1988) and Canale et al. (1990) and the recent results of Patton et al. (2004) who observed a tendency for a decrease in milk protein concentration at 7 and 14 DIM in cows fed both propionate and LCFA.

Effects of treatments on plasma glucose and insulin concentrations showed no effect, which is in contrast to Patton et al. (2004) who found the combination of glucose precursors and LCFA to increase blood glucose and insulin when fed pre- and postpartum. Differences between studies could be attributed to differences in prepartal DMI, diet ether extract content, and the type of glucose precursor used. Prepartal intakes averaged $11.9 \mathrm{~kg} / \mathrm{d}$, whereas those of Patton et al. (2004) were $>15 \mathrm{~kg} / \mathrm{d}$. Although not apparent here, Littledike et al. (1981) explained that propionate may be less palatable than propylene glycol. Perhaps the greater dietary ether extract contributed to decreased intakes in our study. Pre- and postpartal diets of Patton et al. (2004) were 0.6 to 1.9 and 0.5 to 1.4 percentage points lower in ether extract, respectively. In addition, we fed propionate as the sole glucose precursor as opposed to a combination of propionate and propylene glycol used by Patton et al. (2004). We anticipated similar results because, when fed, propylene glycol contributes to the ruminal propionate pool (Grummer et al., 1994; Christensen et al., 1997). An excess of glucogenic nutrients relative to lipogenic nutrients has been proposed (Kronfeld, 1982) as one of the reasons for the onset of ketosis because glucose does not provide acetyl-CoA units necessary for milk fatty acid synthesis, which must therefore be derived from depot fat. It is likely our treatments did not alter blood glucose as treatments did in Patton et al. (2004) because our diets provided sufficient lipogenic nutrients, a speculation supported by Kronfeld (1982).

The minimal effects of treatments on plasma metabolites are indicators that the degree of ketosis observed in the present study was not severe enough to require cows to rely heavily upon an exogenous supply of glucose precursors. Mean concentrations of BHBA during the $21 \mathrm{~d}$ after calving were at or below $15 \mathrm{mg} / \mathrm{dL}$ for groups of cows on the various rations. However, 37 (23.7\%) of 156 individual postpartum samples had 
BHBA concentrations $>12.5 \mathrm{mg} / \mathrm{dL}$, the threshold that Nielen et al. (1994) used to classify cows as experiencing subclinical ketosis. All 4 ration groups were represented by the 18 cows with at least 1 postpartum BHBA $>12.5 \mathrm{mg} / \mathrm{dL}$. Blood ketone concentrations in cows used by Schultz (1958) were also quite low. Schultz (1958) found that feeding $113.5 \mathrm{~g} / \mathrm{d}$ of propionate during the first 6 wk of lactation decreased ketone bodies from 13.5 to $9.7 \mathrm{mg} / \mathrm{dL}$. Similar to our results, Patton et al. (2004) found concentrations of BHBA in plasma to be unaffected by feeding calcium salts of fatty acids in combination with glucose precursors.

Despite the limited degree of ketosis observed, a series of observations are noteworthy in evaluating the effects of feeding LCFA with and without propionate on lipolysis. First, concentrations of plasma NEFA continually increased from $21 \mathrm{~d}$ prepartum to 2 DIM for cows fed PRO relative to cows fed PF1 and PF2. Given that DMI was similar between cows fed PRO and PF1, differences in prepartal plasma NEFA profiles (Figure 4) suggest an energetic advantage when $130 \mathrm{~g} / \mathrm{d}$ of cornstarch is replaced by LCFA in diets supplemented with propionate salts at $198 \mathrm{~g} / \mathrm{d}$. This is especially true considering that the uptake and oxidation of NEFA by hepatic and extrahepatic tissue is directly related to their plasma concentrations (Katz and Bergman, 1969) and accumulation of NEFA in liver exacerbates production losses (Grummer, 1993). Second, the absence of an increase in plasma BHBA with elevated prepartal NEFA indicates the capacity to oxidize fatty acids to $\mathrm{CO}_{2}$ was not exceeded in cows fed PRO (Grummer and Carroll, 1991). Third, prepartal differences in NEFA profiles plotted against time between cows fed PRO vs. PF1 suggest LCFA ingested by cows fed PF1 may have been used to reduce the need for release of NEFA by adipose tissue. This is supported by the fact that $\mathrm{Ca}$ salts of fatty acids escaping rumen fermentation enter the blood as chylomicrons and are readily extracted by the mammary gland, which is rich in lipoprotein lipase (Havel, 1987). Lastly, it appears that feeding greater quantities of propionate in conjunction with LCFA (PF1 vs. PF2) may be justified because of the observed decrease $(P \leq 0.02)$ in concentrations of NEFA in plasma for cows fed $\mathrm{PF} 2$ relative to those fed $\mathrm{PF} 1$. This response is most evident at 2 DIM where concentrations of NEFA in plasma were twice as high in cows fed PF1 relative to those fed PF2 (1111 vs. $552 \mu \mathrm{Eq} / \mathrm{L})$.

\section{CONCLUSIONS}

Supplementing diets for transition dairy cows with propionate and LCFA had minimal effects on lactational performance and blood metabolites. The addition of LCFA to diets of cows receiving propionate tended to decrease feed efficiency (ECM/DMI) during the first 21 DIM. Plasma NEFA profiles suggest a benefit to supplementing propionate and LCFA at greater than 154 and $93 \mathrm{~g} / \mathrm{d}$ prepartum. This indication of improved energy balance is supported by maintenance of DMI during the prepartal period, as cows fed PF2 did not experience a decrease in DMI from week 2 to 1 prepartum (Figure 1). Based upon the glucogenic to lipogenic ratio proposed by Kronfeld (1982) and previous studies (Patton et al., 2004), the magnitude of the response to feeding propionate in combination with LCFA to transition dairy cows may be dependent upon the amount of fat present in the basal diet.

\section{ACKNOWLEDGMENTS}

The authors express appreciation to personnel at the South Dakota State University Dairy Teaching and Research Farm for the feeding and care of the animals. This research was supported, in part, by Pestell Inc., New Hamburg, ON, Canada.

\section{REFERENCES}

Allen, M. S. 2000. Effects of diet on short-term regulation of feed intake by lactating dairy cattle. J. Dairy Sci. 83:1598-1624.

Association of Official Analytical Chemists. 1990. Official Methods of Analysis. 15th ed. AOAC, Arlington, VA.

Association of Official Analytical Chemists. 1997. Official Methods of Analysis. 16th ed. AOAC Intl., Gaithersburg, MD.

Beem, A. E. 2003. Use of urine $\mathrm{pH}$ to predict incidence of ketosis in transition dairy cows. M.S. Thesis. Louisiana State University, Baton Rouge, LA.

Bertics, S. J., R. R. Grummer, C. Cadorniga-Valino, and E. E. Stoddard. 1992. Effect of prepartum dry matter intake on liver triglyceride concentration and early lactation. J. Dairy Sci. 75:19141922.

Canale, C. J., P. L. Burgess, L. D. Muller, and G. A. Varga. 1990. Calcium salts of fatty acids in diets that differ in neutral detergent fiber: Effect on lactation performance and nutrient digestibility. J. Dairy Sci. 73:1031-1038.

Christensen, J. O., R. R. Grummer, F. E. Rasmussen, and S. J. Bertics. 1997. Effect of method of delivery of propylene glycol on plasma metabolites of feed-restricted cattle. J. Dairy Sci. 80:563-568.

Drackley, J. K., T. R. Overton, and G. N. Douglas. 2001. Adaptations of glucose and long-chain fatty acid metabolism in liver of dairy cows during the periparturient period. J. Dairy Sci. 84:100-112.

Emery, R. S., J. S. Liesman, and T. H. Herdt. 1992. Metabolism of long chain fatty acids by ruminant liver. J. Nutr. 122:832-837.

Ferre, P., J. P. Pegorier, E. B. Marliss, and J. R. Girard. 1978. Influence of exogenous fat and gluconeogenic substrates on glucose homeostasis in the newborn rat. Am. J. Physiol. 234:E129-E136.

Goff, J. P., R. L. Horst, P. W. Jardon, C. Borelli, and J. Wedam. 1996. Field trials of an oral calcium propionate paste as an aid to prevent milk fever in periparturient dairy cows. J. Dairy Sci. 79:378-383.

Grum, D. E., J. K. Drackley, R. S. Younkers, D. W. LaCount, and J. J. Veenhuizen. 1996. Nutrition during the dry period and hepatic metabolism of periparturient dairy cows. J. Dairy Sci. 79:1850-1864.

Grummer, R. R. 1988. Influence of prilled fat and calcium salt of palm fatty acids on ruminal fermentation and nutrient digestibility. J. Dairy Sci. 71:117-123.

Grummer, R. R. 1995. Impact of changes in organic nutrient metabolism on feeding the transition dairy cow. J. Anim. Sci. 73:2820-2833. 
Grummer, R. R. 1993. Etiology of lipid-related metabolic disorders in periparturient dairy cows. J. Dairy Sci. 76:3882-3896.

Grummer, R. R., and D. J. Carroll. 1991. Effects of dietary fat on metabolic disorders and reproductive performance of dairy cattle. J. Dairy Sci. 69:3838-3852.

Grummer, R. R., J. C. Winkler, S. J. Bertics, and V. A. Studer. 1994. Effect of propylene glycol dosage during feed restriction on metabolites in blood of prepartum Holstein heifers. J. Dairy Sci. 77:3618-3623.

Havel, R. J. 1987. Lipid transport function of lipoproteins in blood plasma. Am. J. Physiol. 253:1-5.

Hoover, W. H., and S. R. Stokes. 1991. Balancing carbohydrates and proteins for optimum rumen microbial yield. J. Dairy Sci. 74:3630-3644.

Jerred, M. J., D. J. Carroll, D. K. Combs, and R. R. Grummer. 1990. Effect of fat supplementation and immature alfalfa to concentrate ratio on lactation performance of dairy cows. J. Dairy Sci. 73:2842-2854.

Johnson, M. J., and J. P. Peters. 1993. Technical note: An improved method to quantify nonesterified fatty acids in bovine plasma. J. Anim. Sci. 71:753-756.

Katz, M. L., and E. N. Bergman. 1969. Hepatic and portal metabolism of free fatty acids, and ketone bodies in sheep. Am. J. Physiol. 216:953-960.

Kronfeld, D. S. 1982. Major metabolic determinants of milk volume, mammary efficiency, and spontaneous ketosis in dairy cows. J. Dairy Sci. 65:2204-2212.

Littell, R. C., G. A. Milliken, S. W. Walter, and R. D. Wolfinger. 1996. SAS systems for Mixed Models. SAS Institute, Inc., Cary, NC.

Littledike, E. T., J. W. Young, and D. C. Beitz. 1981. Common metabolic diseases of cattle: Ketosis, milk fever, grass tetany, and downer cow complex. J. Dairy Sci. 64:1465-1482.

Lomax, M. A., I. A. Donaldson, and C. I. Pogson. 1986. The effect of fatty acids and starvation on the metabolism of gluconeogenic precursors by isolated sheep liver cells. Biochem. J. 240:277-280.

National Research Council. 2001. Nutrient Requirements of Dairy Cattle. 7th rev. ed. Natl. Acad. Sci., Washington, DC.

Nielen, M., M. G. A. Aarts, A. G. M. Jonkers, T. Wensing, and Y. H. Schukken. 1994. Evaluation of two cowside tests for the detection of subclinical ketosis in dairy cows. Can. Vet. J. 35:229-232.
Oba, M., and M. S. Allen. 2003. Intraruminal infusion of propionate alters feeding behavior and decreases energy intake of lactating dairy cows. J. Nutr. 133:1094-1099.

Orth, R. 1992. Sample Day and Lactation Report. DHIA 200 Fact Sheet A-2. Mid-States DRPC, Ames, IA.

Patton, R. S., C. E. Sorenson, and A. R. Hippen. 2004. Effects of dietary glucogenic precursors and fat on feed intake and carbohydrate status of transition dairy cows. J. Dairy Sci.

Rigout, S., C. Hurtaud, S. Lemosquet, A. Bach, and H. Rulquin. 2003. Lactational effect of propionic acid and duodenal glucose in cows. J. Dairy Sci. 86:243-253.

Salfer, J. A., J. G. Linn, D. E. Otterby, and W. P. Hansen. 1995. Early lactation responses of Holstein cows fed a rumen-inert fat prepartum, postpartum, or both. J. Dairy Sci. 78:368-377.

SAS Institute. 2001. SAS User's Guide. Statistics, Version 8.01 edition. SAS Inst., Inc., Cary, NC.

Schmidt, G. H., and L. H. Schultz. 1958. Effect of feeding sodium propionate on milk and fat production, roughage consumption, blood sugar and blood ketones of dairy cows. J. Dairy Sci. 41:169-175.

Schultz, L. H. 1958. Use of sodium propionate in the prevention of ketosis in dairy cattle. J. Dairy Sci. 41:160-167.

Seal, C. J., and C. K. Reynolds. 1993. Nutritional implications of gastrointestinal and liver metabolism in ruminants. Nutr. Res. Rev. 6:185-208.

Skaar, T. C., R. R. Grummer, M. R. Dentine, and R. H. Stauffacher. 1989. Seasonal effects of prepartum and postpartum fat and niacin feeding on lactation performance and lipid metabolism. J. Dairy Sci. 72:2028-2038.

Trinder, P. 1969. Determination of glucose in blood using glucose oxidase with an alternative oxygen acceptor. Ann. Clin. Biochem. $6: 24-27$.

Van Soest, P. J., J. B. Robertson, and B. A. Lewis. 1991. Methods for dietary fiber, neutral detergent fiber, and nonstarch polysaccharides in relation to animal nutrition. J. Dairy Sci. 74:35833597.

Wildman, E. E., G. M. Jones, P. E. Wagner, R. L. Bowman, H. F. Troutt, Jr., and T. N. Lesch. 1982. A dairy cow body condition scoring system and relationship to selected production characteristics. J. Dairy Sci. 65:495-501.

Williamson, D. H., J. Mellanby, and H. A. Krebs. 1962. Enzymatic determination of $\mathrm{D}(-) \beta$-hydroxybutyrate and acetoacetic acid in blood. Biochem. J. 82:90-96. 